\title{
DAS “DURAS" ÀS MÁQUINAS DO OLHAR a violência e a vigilância na prisão
}

Kiko Goifman

Antropólogo e documentarista. Autor do livro/CD-ROM Valetes em slow motion: a morte do tempo na prisão

\footnotetext{
Na malandragem não pode cagüetar (...)

cagüetou, deu mancada, lamentável.

Preso da P1 - Trecho de "Tereza"1

O vídeo estende diretamente a analogia do movimento ao tempo:

tempo real, instantâneo, que duplica e ultrapassa o tempo

diferido do filme, e do qual as câmeras de vigilância oferecem a

imagem atroz e pura. Invisivel de ser por toda a parte,

cego à força de tudo ver, ele vem para além dos

séculos figurar a visão neutra e negativa do

Cristo Pantocrator, visível e que tudo vê.

Raymond Bellour
}

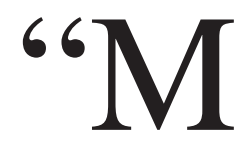

áquinas do olhar" marcam hoje a paisagem urbana. São câmeras espalhadas por locais variados com o intuito de vigiar. Prisões, supermercados, bancos, edifícios, aeroportos usam de circuitos internos de vídeo para a obtenção de imagens que se constituem em ícones contemporâneos. São máquinas que produzem "sujas" imagens em VHS, que têm o objetivo geral de produção de provas.

O presente artigo tem como proposta central a discussão a respeito da violência e da vigilância. Inicialmente, interessa-nos o entendimento do espaço carcerário para, em um segundo momento, chegarmos até uma discussão a respeito da "imagem-vigilante" em geral. O caminho proposto parte de dentro para fora, ou seja, após uma brevíssima passagem pelas formas tradicionais de vigilância em instituições carcerárias, a intenção é transcender os muros chegando à "tecnovigilância" na sociedade contemporânea. Muito vem sendo discutido a esse respeito atualmente e a contribuição aqui pretendida propõe um movimento por essa bibliografia
- percurso que se pauta em diversos autores fundamentais para o debate, procurando ora a sistematização, ora a colocação de questões por outros pontos de vista.

\section{DAS “DURAS” À “CAGÜETAGEM"}

Formas articuladas do vigiar complementam-se na prisão, compreendendo tanto as que envolvem contato físico direto na relação com o guarda como as práticas de delação entre a população carcerária. Além destas, documentação, números, fichários, fotos, relatórios atualizam informações (muitas vezes defasadas, essas fontes não serão tratadas aqui).

Buscas, apreensões, "duras" e "gerais" são mecanismos habituais de uma máquina vigilante que atua, nesses casos, através da proximidade física. Ao preso cabe mostrar-se, ou ainda, ocultar-se de forma competente. O ideal de vigilância é então dependente dos guardas que o atualizam - muitas vezes com brutalidade -, na medida em que este se realiza através da atuação de agentes institucionais que se pautam em estereótipos e, não raro, fazem "vista grossa". Em um ambiente do qual a violência faz parte, qualquer diretor de prisão sabe, conforme dito em entrevista, que "todo preso tem sua arma".

A "vista grossa" aparece como uma situação-limite de tolerância, reconhecidamente praticada e fixada a partir da experiência diária. Em um lugar onde "tudo vira arma" (preso da P1) ${ }^{3}$ ou "onde é mais fácil se conseguir droga" (funcionário do $\mathrm{CRN}$ ), onde as práticas ilegais são incontáveis, os agentes institucionais têm ao seu lado o "direito de olhar", a possibilidade de, em um dado momento, 
deixar de lado a "vista grossa" e organizar buscas destinadas, de fato, a encontrar. Muitos presos já "caíram"4 assim dentro da própria cadeia.

No contato direto, detentos e guardas expõem-se. Os primeiros, objetos da situação concreta de vigilância. Os guardas, testados, colocados "em cheque". É nesse momento que a população presa constrói sua imagem a respeito dos carcereiros. E essa imagem depende da postura destes diante de práticas ou objetos ilegais: "Eles (os guardas) podem ser analisados igual aos internos. Uns valem alguma coisa, outros, nada. Uns impõem um moralismo que eles próprios não têm. Querem te submeter a uma disciplina que eles não possuem" (preso do CRN).

Não raro cruéis e violentas, as buscas têm uma dupla função. Armas e drogas são achadas, algumas vezes apreendidas, mas o essencial da "dura" é a intimidação, a atualização do poder.

Além da vigilância recíproca entre presos e guardas, há outra forma de controle, velada mas reconhecida, no cárcere. É a "cagüetagem" interpresos - uma situação em que "todos se vigiam". A importância dos "cagüetas" (alcagüetes) para a administração do cotidiano carcerário encontra eco na atuação dos guardas. Não são poucos os rituais de extrema violência para a "extração de informações", como de planos de rebelião, emergência de grupos e lideranças, tráfico de drogas intramuros, etc.

Em uma primeira visita ao 5을 Distrito Policial de Campinas, na qual conversamos com vários presos simultaneamente, o líder de cela apontou para um que estava no pátio, com o corpo todo cortado por gilete, afirmando: “... aquele ali é cagüeta, cagüetou na rua, não tem mole pra ele aqui não" (preso do 5ำ DP).

A represália à "cagüetagem" passa a ser considerada normal e a violência plenamente justificada: "Tinha safado, pilantra, que ninguém gosta de safado e pilantra que fica cagüetando os irmão, então saía assim, vai morrer. E matava" (preso da P1).

Esse mesmo detento relatou uma situação em que a morte foi considerada o melhor mecanismo para dar fim à "cagüetagem"; porém, tratava-se de um equívoco, e quando se constatou isto já era tarde demais para remediálo: "Os cara induziu ele, levou ele pro barraco do cara. Aí um cara falou, quem cagüetou foi ele, mataram o cara. Aí depois de quase um ano foram descobrir que quem morreu era inocente e o cara que acendeu pra matar era o cagüeta" (preso da P1).

Outro preso entrevistado na P1 afirmou ter escapado por pouco da morte após uma "cagüetagem". Esse detento tem um primo policial e ocultava isso na prisão por achar que poderia ser malvisto. Um outro preso descobriu e se encarregou de passar adiante a informação. $\mathrm{O}$ que torna interessante esta história é que um detento delata com medo de ser delatado por práticas proibidas na prisão. "Cagüeta-se", por prevenção, contra a "cagüetagem".

A delação, mais até que a própria personificação do delator, introduz, do ponto de vista espacial, um recorte significativo. A exposição a que os presos se submetem ganha um novo contorno, apresenta seu lado mais perverso e não menos eficaz. $\mathrm{O}$ vigilante e o vigiado ocupam o mesmo espaço, dificilmente diagnosticado e no qual pode agir. O vigia também é o vizinho, "o irmão no qual não se pode confiar" (preso do CRN.). Não há fronteira espacial e a única defesa com relação a estes é a coerção, a punição, não raro a morte, como forma de proteção em um espaço marcado pela exposição e, por que não, pela visibilidade. A delação é ainda motivadora da "necessidade" da aceleração do tempo na prisão, na medida em que a demora na efetivação de um plano de fuga pode levá-lo ao fracasso. A demora fragiliza a ação.

\section{O PANÓPTICO HOJE}

A partir do que foi dito, pode-se chegar ao centro da discussão proposta, que associa a vigilância aos dispositivos que vão além do contato interpessoal. Deixando a relação entre homens, o percurso agora vai até a figura dos equipamentos de vigiar. O espaço ideal da prisão constitui-se em uma máquina de segurança e, nesse limite, trafega sua arquitetura. Um projeto arquitetônico de prisão pauta-se pela funcionalidade, pois o bem-estar de infratores não é representado socialmente como algo relevante. Ao contrário, ao parecer fisicamente de forma sombria, com certo ar deteriorado, inclusive, afigura-se a possibilidade de que os que lá estão realmente sofrem pelo erro que cometeram. Com o estreitamento da relação entre práticas consideradas científicas - como a psicologia aplicada, o diagnóstico do infrator, etc. - aperfeiçoou-se também a forma de entendimento do espaço físico da prisão. O projeto arquitetônico mais célebre, e também o mais particular, recebeu o nome de panóptico. A idéia de panoptismo remonta ao princípio de vigilância formulado pelo - ou atribuído ao - jurista britânico Jeremy Bentham, no século XIX.

Em Vigiar e punir, Foucault (1991:177) apresenta as características fundamentais do panoptismo, em que a vigilância aparece como a noção central do modelo e tam- 
bém como a perspectiva utilitária de uma economia eficaz na administração de espaço e tempo do vigiar. O filósofo descreve sintética e precisamente este modelo:

"O Panóptico de Bentham é a figura arquitetural dessa composição. O princípio é conhecido: na periferia uma construção em anel; no centro, uma torre; esta é vazada de largas janelas que se abrem sobre a face interna do anel; a construção periférica é dividida em celas, cada uma atravessando toda a espessura da construção; elas têm duas janelas, uma para o interior, correspondendo às janelas da torre; outra, que dá para o exterior, permite que a luz atravesse a cela de lado a lado. Basta então colocar um vigia na torre central, e em cada cela trancar um louco, um doente, um condenado, um operário ou um escolar. Pelo efeito de contraluz, pode-se perceber da torre, recortando-se exatamente sobre a claridade, as pequenas silhuetas cativas nas celas da periferia. Tantas jaulas, tantos pequenos teatros, em que cada ator está sozinho, perfeitamente individualizado e constantemente visível. O dispositivo panóptico organiza unidades espaciais que permitem ver sem parar e reconhecer imediatamente. Em suma, o princípio da masmorra é invertido; ou antes, de suas três funções - trancar, privar de luz e esconder - só se conserva a primeira e suprimem-se as outras duas. A plena luz e o olhar de um vigia captam melhor que a sombra, que finalmente protegia. A visibilidade é uma armadilha."

A superexposição unilateral sustenta a organização da forma espacial. A luz delimitando o contorno em movimento constrói a mensagem que será decodificada por um vigia. O preso não vê o outro, o sujeito que vigia. Uma possível individualização do espaço mostra somente a sua pior face para o preso, priva-o do contato coletivo, impedindo organizações de quaisquer gêneros, e não lhe oferece a privacidade, já que a intenção é sujeitá-lo ao olhar permanente.

A dúvida sobre a necessidade ou não de celas individuais e do "não-contato" entre presos para o funcionamento do modelo panóptico é questionada por Duprat (1980). Posteriormente, Melossi (Melossi e Pavarini, 1985) esclarece que o isolamento era destacado no primeiro projeto de Bentham, e depois substituído por celas com maior número de presos.

O ponto central do panoptismo, sobre o qual parecem concordar diversos autores, é a sensação incorporada de estar sendo vigiado, que é mais importante inclusive do que a observação de fato. Não vendo o olho do vigia, a possibilidade deste estar distraído é ausente, a torre em si torna contínuo o olhar da direção.
O rompimento da unilateralidade do olhar só ocorre de forma previsível, como assinala Muricy (1993:484): "Bentham abre uma exceção para a invisibilidade do olharvigia. A torre do inspetor poderá, no domingo, transformar-se em uma capela, acolher os fiéis do exterior. Neste dia, as persianas poderão se abrir e os prisioneiros verão e ouvirão o padre que oficia. Desta vez, o olho de Deus ocupará a torre."

Formula-se, então, um ideal de altar, no qual é possível "ver Deus", simultaneamente próximo e inalcançável. Não existe problema em se ver o padre. Diferentemente do vigia, este não traz da janela um saber falível - não errará -, e nem sua presença física é referência carnal ou forma de cheque de dogmas. "Transparente", torna-se "lente-janela" para se enxergar Deus.

A máquina do panóptico, conforme a expressão de Foucault (1991), potencializa uma economia de espaço e tempo. A brutalidade do confronto direto para a implementação do poder torna-se descartável. Os espaços para rituais de renovação dos imperativos de ordem tornamse, não raro, supérfluos. O número de vigilantes é reduzido bruscamente. A eficácia instantânea da observação da desobediência acelera o tempo para a punição. A imagem do preso, através da televisão, chega "direta" e "ao vivo" para o controle imediato de qualquer esboço indisciplinar. Não há dúvidas quanto à identificação do sujeito em sua falta. Não há como delegar ou distribuir a culpa.

Princípio arquitetural, "casa de certeza" ou "campo de visibilidade" (Foucault, 1991), a noção de panoptismo não foi fixada exclusivamente para prisão, mas como um modo ideal de vigilância plenamente adaptável a qualquer instituição. Para este autor, trata-se de um "laboratório de poder", sustentado tanto na possibilidade de observação quanto na eficácia de introjeção, e, por conseguinte, de uma alteração comportamental: "É o diagrama de um mecanismo de poder levado à sua forma ideal (...), é na realidade uma figura de tecnologia política que se pode e se deve destacar de qualquer uso específico" (Foucault, 1991:181).

Associada à idéia de abertura e fechamento, a eficácia da totalidade do panóptico mostra-se exatamente pela alusão à permeabilidade interior-exterior. Nem mesmo a introdução de pessoas "de fora" acompanhando a vigilância impediria seu funcionamento. Ao contrário, poder-se-ia imaginar uma vitrine, em que é ainda um elemento físico do exterior, a luz, que assegura seu eficaz movimento. Uma vitrine particular, na qual quem está no interior desconhece seu observador. Uma "máquina anônima", nas palavras de Machado (1991). 
Como modelo, não se justifica que encontremos atualmente por todos os lados instituições circulares, mas o mais importante é identificar princípios similares de nítida e assumida inspiração ou não. É quanto a esse aspecto que a reflexão sobre o uso de câmeras de circuito fechado em instituições carcerárias pode ser pautada nos princípios do panoptismo. Machado, que é pesquisador de linguagens eletrônicas, destina um de seus artigos, "A cultura da vigilância", a esse tema. Lembra que o uso de câmeras de vídeo em prisões modernas remonta ao velho princípio panóptico, concordando inclusive com Foucault que a sociedade atual tende antes à vigilância que ao espetáculo.

$O$ pesquisador de prisões no período da revolução industrial (notadamente a de Pentonville), Michel Ignatieff (1978), segundo o qual o panóptico foi definitivamente rejeitado em 1810, também associa novas tecnologias a alguns princípios da concepção modelar formulada por Jeremy Bentham, destacadamente as câmeras de TV e os detetores de metal e calor.

A experiência de síntese de espaço e tempo na perspectiva da economia de vigilância parece ser a renovação do princípio panóptico através da utilização das câmeras de vídeo. Essa discussão poderia sugerir algo distante de nossa realidade, em função do atual estado de deterioração das prisões brasileiras e do alto custo aparente de implantação de sistemas desse porte. Em primeiro lugar, é preciso deixar claro que o custo das tecnologias de produção de imagem eletrônica já está bastante reduzido, e, tendo em vista que para um circuito interno de TV a qualidade de cores e a definição não são aspectos essenciais, o preço deixa de ser um problema. ${ }^{5} \mathrm{O}$ segundo aspecto é que se, além do baixo custo, se considerar a possibilidade de redução do corpo de vigilantes, a economia será significativa. As prisões atuais apresentam com frequiência espaços coletivos. Nas penitenciárias, há uma área de convívio interpresos onde estes passam ali a maior parte do tempo de pena a cumprir, como também áreas de trânsito, normalmente largos corredores onde a vigilância é um imperativo em um espaço considerado de frágil segurança. $\mathrm{Na}$ P1, é nesses locais, e também nos arredores da prisão, que estão dispostas as oito câmeras do sistema.

É preciso deixar claro em que aspectos se verifica a incorporação do princípio panóptico na utilização das câmeras. O primeiro fundamento é o da visão unilateral. Os presos, ainda que vejam a câmera, desconhecem quem está por trás dela, controlando monitores que jogam as imagens sem parar. Obedece-se a um dos princípios cen- trais do panóptico, que é a "desindividualização e despersonificação do poder". ${ }^{6}$ Outro fato é a sensação de estar sendo vigiado. As câmeras utilizadas com esse fim não emitem nenhum sinal que evidencie se estão ou não ligadas. Se estão com defeito, desligadas por economia de energia, pouco importa, elas continuam ali, apontando sua lente objetiva para todos os presos e os espaços.

As áreas coletivas da prisão não podem, então, ser escuras. A luz que define o contorno dos atos do preso no modelo panóptico aparece aqui com a função de garantir a nitidez mínima das imagens. Quanto maior a luz, mais possibilidades de detectar com eficácia o infrator, já que as câmeras funcionam em plano aberto otimizando o raio do espaço vigiado. Comentado o trabalho de Foucault, Deleuze (1988:41) vai além:

“A prisão, por seu lado, diz respeito ao visível: ela não apenas pretende mostrar o crime e o criminoso, mas ela própria constitui uma visibilidade, é um regime de luz antes de ser uma figura de pedra, define-se pelo 'Panoptismo', isto é, por um agenciamento visual e um meio luminoso do qual o vigia pode ver tudo sem ser visto, no qual os detidos podem ser vistos, a cada instante, sem verem a si próprios (...)."

Através da lógica da luz, chega-se à discussão sobre visibilidade e transparência no interior da prisão instituição que, por princípio, apresenta-se como "não transparente". No modelo panóptico, a noção de secreto apresenta-se de forma unilateral. Não se esconde a sensação do vigiar, de estar sendo vigiado (transparência). Esconde-se exclusivamente quem está vigiando e se este está ou não exercendo sua tarefa (opacidade).

É interessante ainda procurar compreender como as câmeras amplificam o princípio panóptico com a inclusão de novas facetas. Assim como no modelo de Bentham, a instantaneidade entre o tempo da infração e o conhecimento desta pela administração se verifica. É esfacelada a duração entre o delito intramuros e a observação deste. Assim, o tempo entre a "falta" e o castigo pode também ser encurtado. O que aparece como novidade no "panóptico eletrônico" é exatamente a produção da prova instantânea. Contra argumentos que delegam a culpabilidade a outro preso, apresenta-se a "tecno-imagem" de sua ação. Intransferível, o erro pode ser individualizado. Personalizado, não há como negá-lo. Na prisão, a imagem eletrônica do erro do preso constitui-se em prova. Não se desconfia - ao menos por ora - do olhar da câmera, que, diferentemente do agente institucional, apresenta-se fora de suspeitas. 


\section{A P1 NA PERSPECTIVA DO PANÓPTICO CONTEMPORÂNEO}

Como foi dito anteriormente, para a coleta de dados desta pesquisa foram feitas visitas ao CRN/MG, ao 5은 Distrito Policial de Campinas e à Penitenciária 1 (P1). A maior parte do trabalho de campo foi feita nesta última, durante o ano de 1992. Recente, construída durante o governo Quércia, e inaugurada em 1989, a P1 chegou a fazer parte do Complexo Penitenciário Ataliba Nogueira, em Campinas. Posteriormente, o complexo foi desmembrado em instituições e diretorias diferentes, não havendo nenhuma ligação entre a P1 e a P2, apesar da proximidade física, e a tradicional Penitenciária Ataliba Nogueira foi destinada exclusivamente a presos em regime semiaberto ou aberto. Na P1 e na P2 estão os condenados em fase de regime fechado. A "prisão tradicional" de Campinas, o "cadeião", como é chamado o Presídio São Bernardo, estava em reformas, o que impediu que o trabalho de campo fosse realizado nessa instituição.

A Penitenciária 1 de Campinas/Sumaré não se aproxima da imagem tradicional das prisões brasileiras, com celas quebradas e deterioradas. Considerada de porte médio, abrigava então 630 presos, embora a capacidade ideal estimada fosse de 538 detentos. Ainda que sem a riqueza da descrição visual, apresentamos alguns aspectos do espaço da P1 para então discutir a idéia do panoptismo nesse ambiente.

Portões fortes e maciços fecham as celas, havendo apenas um espaço vazado para o recebimento de alimentação e roupas de cama. É através dessa "portinhola" que "é paga a bóia", expressão dos presos que designa o recebimento da comida. Acima, na altura dos olhos, um retângulo de vidro grosso permite que os presos vislumbrem trechos do pavilhão. Qualquer movimento ou som diferente é o suficiente para que centenas de pares de olhos disputem um lugar nos pequenos segmentos de vidro embaçado e nas "portinholas" que, a princípio, deveriam permanecer fechadas. Muitas, porém, estão estragadas, o que talvez sejam os primeiros sinais de deterioração material, enquanto outras são habilmente abertas por ferramentas construídas pelos presos. No fundo das celas, pequenas janelas com grades completam os espaços que ligam os cubículos a outros locais do interior da prisão. As pequenas aberturas nas maciças portas das celas são antes o local por onde o guarda olha do que o oposto. Esse é o espaço que permite a instauração da "microvigilância".
A penitenciária é dividida em três pavilhões chamados "raios". O raio 1 é o mais próximo da administração e, não por acaso, comporta os presos de menor periculosidade e os considerados recuperados. Os raios 2 e 3 , com celas maiores e mais populosas, ficam no fundo da penitenciária, havendo um longo corredor entre eles e a principal porta de saída. ${ }^{7}$ Cada raio tem um pátio particular, de cimento, com um campo de futebol, o que isola a população de um pavilhão em relação ao outro.

A imagem de um ambiente sujo, malcuidado, freqüente em prisões brasileiras (este é o caso do $5^{\circ}$ Distrito Policial) também não é a norma na $\mathrm{P} 1$. Se não fosse a existência de signos que nos remetem de imediato à idéia de cárcere, como algumas grades, rádios de comunicação, "gaiolas" de ferro, talvez a confusão com um sombrio hospital de péssimo gosto fosse possível. O ferro dá o tom de prisão. "Cadeia é feita de ferro, qualquer lugar que se vai se tira uma faca" (preso da P1).

O extenso corredor da penitenciária, do qual saem todos os caminhos, pode ser visto como a passagem principal. Uma adaptação do modelo panóptico em cruz, com duas transversais horizontais. No comprido corredor, todos que fazem seu trajeto são interrompidos por "gaiolas", pequenos cercados de grades que dão acesso aos pátios e limitam o trânsito. Nessas "gaiolas" um funcionário comanda o movimento, organizando os que devem passar.

As paradas de controle, "gaiolas", são revestidas de grades até o teto e o "guarda do trânsito" situa-se em um local alto, onde está seguro e pode vigiar o que se passa. O chão do corredor é dividido em três faixas. Duas são estreitas, próximas às paredes, por onde os presos devem caminhar com as mãos para trás e em fila. A faixa central é destinada ao trânsito de funcionários e eventuais visitas.

Além das "gaiolas", outro aspecto que marca o poder de vigilância desse corredor é o circuito fechado de TV. Quando se avança por ele, sabe-se que atrás existe uma câmera e que se caminha em direção a outra. Durante o percurso, os presos podem ser vistos por vários ângulos, e mesmo quando cruzam uma gaiola, não é só o vigia que os observa. As câmeras são organizadas com o intuito de criar uma rede contínua de vigilância, de modo que aquilo que uma deixa de mostrar é captado por outra.

Os presos não devem olhar para as câmeras. Eles cruzam a extensão do corredor com a cabeça baixa. As câmeras ficam expostas, mas não se pode olhar para elas, apenas eventualmente, como que para se assegurar de que continuam ali. 
Em uma sala distante, cercada de alarmes, um funcionário observa e, mais do que isso, pode gravar o que está sendo mostrado. Aqui a imagem é antes de tudo documento. Se um guarda faz vista grossa a irregularidades o que é comum -, a câmera pode registrar. Se está gravado é real. Aqui onde máquinas de escrever não foram trocadas por computadores, a imagem ainda possui um status ontológico de verdade. A maior virtude do circuito não é catalogar falhas dos internos, visto que as acusações de funcionários e a "cagüetagem" são suficientes para incriminar os já criminosos. O circuito fechado e a presença de câmeras funcionam como eficientes vigilantes introjetados.

Para ingressarmos na sala de controle das câmeras, foram necessárias longas negociações com o diretor, o que revela o valor positivo que ele atribuía àquele sistema recentemente implantado. Durante várias visitas à prisão, buscou-se um acordo para que fosse liberada a gravação de imagens dessa sala - denominada por alguns funcionários de "cérebro da segurança". Termo estranho esse, tendo em vista o caráter inaugural do sistema. Depois de muitas ordens e contra-ordens, no dia anterior à primeira gravação em vídeo ficou estabelecido que apenas imagens tomadas pelo próprio circuito fechado nos seriam entregues. Providenciamos uma fita VHS para a cópia, mas nem isto foi permitido. Só foi possível entrar sem a câmera. O que vimos na sala foram oito telas, das quais duas estavam com defeito e nada mostravam, enquanto as outras "cobriam" diferentes espaços da penitenciária. De todas as câmeras, apenas uma tinha movimento, acionada por controle remoto, fazendo com que realizasse, em torno de seu eixo, uma pequena alteração de sua posição inicial. A pessoa encarregada da observação era um técnico em eletrônica e não um guarda. Nenhum funcionário da prisão estava habilitado a tomar o comando das funções. Como sustenta Machado, "essas máquinas, a rigor, vigiam muito pouco" (1991:96).

Em uma das visitas, fomos acompanhados pelo diretor de disciplina, que, com orgulho, pedia ao técnico para mostrar-me as possibilidades do circuito. Enquanto reconhecíamos os cantos da prisão pelas câmeras, uma delas flagrou um carcereiro lendo jornal, nas "gaiolas" do corredor. Imediatamente, o diretor pegou o telefone interno e chamou a atenção do guarda que, assustado, sequer respondeu. Pelo monitor, observamos sua desconfortável situação e o jornal sendo colocado em um canto. Por este fato, foi possível compreender que uma das funções daquele sistema era observar os próprios guardas. Esse fato não é uma possibilidade recente. A concepção da despersonalização da vigilância alcança ainda esta figura última do "vigia do vigia", já prevista nas formulações de Bentham.

Relacionado à perspectiva do estar diante de câmeras, um fato ocorrido durante a realização da pesquisa apresenta aspectos que alimentam esta discussão. Convidei um fotógrafo para ir à P1 antes das gravações em vídeo para observar as condições de luz e para que os internos se acostumassem com as câmeras. Depois de várias fotos, pretendíamos registrar pela "portinhola de vidro" uma cela onde dois presos riam e conversavam. Pedi autorização para fotografar, o que foi concedido de imediato. Mas quando o fotógrafo se colocou em posição, os presos mudaram sua postura inicial: um sentou-se e o outro ficou de pé com as mãos para trás, ambos cabisbaixos expressando tristeza. Provavelmente, acharam que era essa a imagem que esperávamos de presos. Era a mesma postura dos presos ao cruzar os corredores e passar diante das câmeras de circuito fechado.

Algumas diferenças pareciam evidentes entre a experiência com vídeo realizada para esta pesquisa e as câmeras que já estavam na prisão. Os presos sabiam quem éramos, nós nos mostrávamos a eles. Na medida em que nenhuma imagem era "furtada", uma nítida oposição entre nossas lentes e as objetivas do sistema de vigilância da prisão ficava marcada. Os presos sabiam o momento exato em que nossas câmeras seriam ligadas, falariam se quisessem, enfim, tinham uma autonomia que seria impensável em se tratando dos dispositivos eletrônicos de vigilância.

A idéia de limite se revela fundamental para a compreensão do espaço da vigilância na prisão. Limita-se, para conter e vigiar, o espaço de circulação do preso. Muros e grades distinguem o mundo de cá e o de lá. Refletindo sobre a P1, é possível perceber que atualmente se opta por dispositivos mais eficazes de imposição de limites do que as grossas paredes. É claro que elas, muitas vezes, permanecem, mas a idéia de labirintos de fortes paredes que se sucedem até o limite da rua é substituída por um arranjo de formas plurais de fronteiras que apontam para a visibilidade. Paredes de ferro em celas, em oposição a grades, corredores expostos com grades nas passagens, cercas de arame e torres em volta. Duas formas de segurança vão se aperfeiçoando com o tempo, assim como ocorre com as fugas. Uma é a cerca de arame, que, conforme relatado por um funcionário "é importada e corta a carne de quem tentar transpô-la". Outra é a torre que, não 
distante da idéia do panoptismo de vigiar sem ser visto, ocupa o espaço em volta dos pavilhões, tendo no alto policiais militares. Armada em um pequeno descampado, condição difícil em grandes centros, atualmente, onde as prisões estão cada vez mais próximas de bairros, o mato baixo dificulta a fuga de quem se arrisca. Lá, ao contrário do 5ํㅜ DP, o "tatu" (buraco) é mais usado que a "tereza" (corda).

\section{O PANÓPTICO ALÉM DOS MUROS}

Um dos aspectos essenciais da leitura que Foucault faz do modelo panóptico de Bentham é que ele transcende a prisão. Mais do que um dispositivo carcerário, o panoptismo era uma possibilidade, já prevista por Bentham, de incorporação da vigilância pelo sujeito observado, que em muito se distanciava de um uso exclusivo.

Ora de forma discreta, ora de forma anunciada, câmeras são instaladas com o objetivo, muitas vezes não assumido, de vigiar. Condomínios, elevadores, aeroportos, supermercados, prisões, shopping centers transformamse em espaços onde cada ato pode ser medido. A própria rua se converte em lugar de vigilância. Nos últimos anos, na cidade de São Paulo, foram instaladas inúmeras câmeras, que impregnam o espaço público urbano com poderosas máquinas do olhar.

Temos nossos atos vigiados cotidianamente e nossas imagens registradas. Podemos imaginar um acervo de atualização incessante no qual uma cartografia em imagens é desenhada. Somos atores, normalmente passivos, de um imenso documentário e sequer podemos ter acesso direto às suas finalidades. Quem já teve a oportunidade de visitar uma das centrais de monitoramento do CET, órgão responsável pelo controle do trânsito em São Paulo, depara-se com um cenário que lembra uma imagem muito comum em filmes de ficção. ${ }^{8}$ Diante de homens orgulhosos com suas máquinas de alto poder de aproximação de imagem, sobra tempo para "brincadeiras". Uma janela, um senhor que passava, enfim, tudo era convertido em objeto de olhar. Indagado se o equipamento não deveria ter seu uso restringido ao controle do trânsito, o responsável de pronto respondeu que não havia por que impedir outros usos. Basta ligarmos a televisão para vermos as imagens fornecidas por essa central preenchendo as grades de programação de algumas emissoras.

Interessa-nos a proliferação de circuitos fechados que se propõem a enxergar, iluminar. $\mathrm{O}$ controle do trânsito passa a ser apontado como argumento motivacional para a instalação generalizada da parafernália da vigilância.
Dispositivos óticos, fotoelétricos, eletrônicos começam a ser implantados no Brasil, em diversas cidades.

De certo modo, o estudo em prisões apresenta possibilidades de conhecimento de uma realidade específica, porém, generalizável. A prisão aparece como um locus muitas vezes privilegiado de apreensão de aspectos sociais peculiares, mas não exclusivos. Algo como a figura de uma metonímia, pois, sendo parte de um todo, encontram-se muitas das características gerais acentuadas. A prisão é um local particular para a compreensão das interfaces cada vez mais presentes na discussão sobre a vigilância e as noções de público e privado. $\mathrm{O}$ espaço da cela, para o qual muitos presos levam objetos com a intenção de transformá-lo de certo modo em "espaço da casa", em instantes torna-se violável ao olhar do outro. Entretanto, essa não é uma característica exclusiva da prisão, ainda que institucionalmente apareça com uma nitidez imediata.

A idéia de vigilância contemporânea transcende a utilização de câmeras, indo em direção a outros mecanismos. Os mesmos espelhos que mostram de vários ângulos nossas imagens em um metrô ou em um shopping center estão presentes em prisões. No presídio de Bangu 1, no Rio de Janeiro, "o interior é vigiado, durante 24 horas, através de um vidro espelhado".9

No "mundo da rua", Paul Virilio (1993b:8) diagnostica uma situação atual de "proliferação de câmeras, radares e detetores nos locais de passagem obrigatória": "Observemos que as prisões francesas que possuem 'setores de segurança máxima' iriam ser equipadas com estes mesmos pórticos magnéticos instalados há alguns anos nos aeroportos, o equipamento da maior liberdade de deslocamento, servindo paradoxalmente como modelo para o de encarceramento penitenciário. Em diversas áreas residenciais americanas, o policiamento é feito apenas através de um circuito fechado de televisão ligado ao posto (estação? delegacia?) central da cidade."

Detectando objetos proibidos, magnética ou eletronicamente, poupa-se o contato direto, e desse modo previnem-se falhas decorrentes de desatenção ou de erros, assim como possibilidades de suborno. Entrega-se, então, a um vigilante "sem rosto" - a máquina - o dever do vigiar. ${ }^{10}$

Um dos aspectos que marca a extensão do panoptismo ${ }^{11}$ para além do espaço carcerário é a disseminação de câmeras de fotos e vídeo. Festas, atualmente, são registradas em minúcias, muitas vezes optando-se por valorizar positivamente mais o signo do que a coisa em si, ou seja, a festa. Esta não interessa se não puder ser inteiramente 
registrada. Vale a pena, então, sacrificar a própria fruição do momento para a observação posterior. O que existe de peculiar nessa experiência moderna, além da alteração no eixo temporal do prazer, que passa a ser adiado para o momento da revelação ou de assistir ao vídeo, é que nos habituamos ao registro eletrônico e químico de termos nossas faces exploradas por um close-up (plano extremamente fechado). Temos nossos gestos vigiados como os de presos, mesmo quando estamos em rituais de desordem.

Cidades turísticas transformaram-se em locus de proliferação de equipamentos óticos usados para as lembranças de viagens. Obviamente, as intenções do registro são outras, mas passamos a considerar normal que lentes objetivas fixem nossas imagens. Como afirma Machado: "As câmeras de vigilância se distribuem como uma rede sobre a paisagem social, ocupando todos os espaços e os submetendo ao seu poder de invasão branca, à sua penetração invisível e indolor" (Machado, 1991:92).

Lentes, perversas ou não, vazam nossos corpos, vasculham nossas posturas. Espelhos na loja, no shopping center, multiplicam nossas imagens e nos colocam em evidência. Nas ruas podemos ter nossas imagens gravadas pelos inúmeros programas de televisão que instalam câmeras escondidas em busca de vexames. Superexpostos ao olhar do outro, somos oferecidos, podemos ser medidos, identificados. A vigilância e o controle de informações transformam-se em práticas rotineiras.

Algumas análises identificam a existência de focos para os quais são apontadas as câmeras, rompendo qualquer perspectiva democrática do exercício da vigilância, que não se configura na expressão todos-vigiam-todos. Como na prisão, o exercício da transparência é unilateral e tópico.

O status da imagem como prova - que transcende o caráter de vigilância, de prática inibidora - indica pistas interessantes para a reflexão sobre a situação genérica da imagem. Enquanto a manipulação de imagens através de processos digitais aponta no sentido do questionamento quanto ao que hoje é o real ou o falso, o referente perde-se ou ao menos está distante; a idéia de circuitos fechados é a pura referência. Além de serem exibicionistas - afinal as câmeras e monitores de circuitos de TV estão normalmente à mostra -, esperase ainda dessas câmeras, nas ocasiões em que estão funcionando de fato, que produzam provas. O diretor geral do CRN que pôs fim às nossas entradas com a câmera naquela prisão, alegou: "Não tenho nada a esconder, mas se você quiser mostrar alguma coisa que pre- judique minha imagem não vou poder fazer nada. Você vai ter as provas que quiser contra mim. Com caneta e papel você entra" (trecho do caderno de campo).

Por enquanto, os circuitos fechados estão entregues a agências nas quais a sociedade deposita confiança, como firmas de segurança ou setores da polícia. Não se espera destas a manipulação das imagens. O que deve ficar claro é que a alteração em imagens ou da posse destas é tecnológica e politicamente possível, apresentando-se, então, a dualidade na qual se sustenta esta discussão: ao mesmo tempo que a imagem, atualmente, pode cada vez mais se afastar, descolar-se do real, criar situações ou mundos virtuais, ela se cola ao real como prova de fatos que aconteceram. Mantida esta convivência, talvez tenhamos de que nos defrontar, em um futuro breve, com inúmeras provas virtuais ou, ainda, falsas provas. A cada momento se faz mais presente a figura de um "tecno-detetive" contemporâneo, capaz de lidar com incessantes inovações tecnológicas.

Em uma sala distante, monitores. Controlando essas máquinas de produção de imagens, um vigia. Com o poder de olhar ampliado esse voyer absoluto constitui-se em uma figura imbuída de poder. Rasgar paredes e adentrar em espaços antes obscuros. Ao lado do peso dos centros urbanos a luminosidade e a transparência. Não uma transparência singela, mas a visibilidade de olhos que a tudo controlam. Uma luminosidade perversa é lançada em nossas cidades. São "máquinas" e homens que operam em tempo real.

\section{NOTAS}

E-mail do autor: goifman@ hotmail.com

Parte da discussão aqui apresentada foi desenvolvida por um outro percurso em Goifman, 1998. Nessa ocasião a discussão aparece relacionada de forma essencial à questão do tempo na experiência carcerária, com a oportunidade de um detalhamento maior com relação às formas de vigilância interpessoais. Nesse livro, o ponto de partida é a pesquisa empírica - Penitenciária 1 de Hortolândia/ $\mathrm{SP}-$, que fundamenta também esse artigo.

1. "Tereza" é o título de um documentário, realizado em 1992, por este autor, em parceria com Caco Pereira de Souza, que trata do cotidiano da prisão.

2. "Duras" e "gerais" são formas de exercício da vigilância que se constituem em inspeções, revistas, no corpo ou nas celas, visando encontrar alguma irregularidade, por exemplo, o porte de drogas ou armas.

3. Penitenciária 1 de Hortolândia, chamada aqui de P1. Parte da pesquisa foi realizada também no Centro Reeducacional de Ribeirão das Neves, Minas Gerais, ou CRN, e no $5^{\circ}$ Distrito Policial de Campinas (5ํDP).

4. "Cair" no "mundo da rua" significa ser preso, dentro é ser descoberto em flagrante, "se dar mal".

5. Fora da prisão, a dificuldade de reconhecimento dos criminosos nas precárias imagens começa a ser questionada. Dispositivos fotográficos, que disparam em intervalos programáveis assim acionados, passam a ser utilizados em larga escala.

6. Aspectos apontados por Foucault (1991). 
7. Em geral, a distribuição de presos no espaço carcerário obedece esse princípio pelo qual os mais perigosos ficam na parte dos fundos da prisão. Recuperarse, ou dar essa impressão, significa também uma transição entre o "fundão" e os espaços da prisão mais próximos da administração, segundo Ramalho (1979).

8. Vários filmes abordam essa questão. Veja-se, por exemplo, O fim da violência, do diretor alemão Wim Wenders.

9. Jornal do Brasil, 28/03/1993.

10. Experiências punitivas em substituição à prisão vêm sendo feitas principalmente a partir da idéia de não exclusão social acompanhada de severa vigilância. Um exemplo desse tipo de experiência é descrito na Folha de S.Paulo de 22/04/1992, no caderno Informática: "Em vários Estados norte-americanos, a Justiça vem usando um sistema eletrônico para controlar pessoas em regime de prisão domiciliar (...). Trata-se de uma pequena tornozeleira que pode, inclusive, ficar escondida sob a roupa e que envia sinais para um computador quando a pessoa sai de determinada área - sua casa, por exemplo (...)." O sucesso desse mecanismo porém é colocado em cheque na própria matéria. O primeiro que conseguiu se libertar da tornozeleira "(...) matou um homem com um tiro e foi novamente pego pela polícia".

11. O tema da vigilância está presente em diversas obras artísticas, como são exemplos a exposição coletiva Surveillance, em Los Angeles, em 1987 (Machado, 1993a); o trabalho Der Riese de Michel Klier (Virilio, 1989), uma montagem de imagens registradas por câmeras automáticas de vigilância.

\section{REFERÊNCIAS BIBLIOGRÁFICAS}

BELLOUR, R. "A dupla hélice". In: PARENTE, A. (org.). Imagem-máquina: a era das tecnologias do virtual. Rio de Janeiro, Ed. 34, 1993.

BENTHAM, J. "Uma introdução aos princípios da moral e da legislação". In: BENTHAM, S.M. São Paulo, Abril Cultural, 1979 (Col. Os Pensadores).

DELEUZE, G. Foucault. São Paulo, Brasiliense, 1988.
DUPRAT, C. "Punir et guerrir - en 1819, la prison des philanthropes". In: PERROT, M. (org.). L' impossible prison. Paris, Éditions du Seuil, 1980.

FOUCAULT, M. Microfísica do poder. Rio de Janeiro, Graal, 1979. Vozes, 1991

GOIFMAN, K. Valetes em slow motion: a morte do tempo na prisão. Campinas, Editora da Unicamp, 1998.

IGNATIEFF, M. A just measure of pain: the penitentiary in the Industrial Revolution, 1750-1850. Nova Iorque, Columbia University Press, 1978.

MACHADO, A. "A cultura da vigilância”. In: NOVAES, A. (org.). Rede imaginária: televisão e democracia. São Paulo, Companhia das Letras, 1991.

. "O vídeo e sua linguagem". Revista USP, n.16, 1992/93, p.6-17.

. "Anamorfoses cronotópicas ou a quarta dimensão da imagem". In: PARENTE, A. (org.). Imagem-máquina: a era das tecnologias do virtual. Rio de Janeiro, Editora 34, 1993a.

Máquina-imaginário: o desafio das poéticas tecnológicas. São Paulo, Edusp, 1993b.

MELOSSI, D. e PAVARINI, M. Cárcel y fábrica - los origenes del sistema penitenciario (siglos XVI-XIX). 2 ed., México, Siglo Veintiuno, 1985.

MURICY, K. "Os olhos do poder". In: $O$ olhar. 4르 ed., São Paulo, Companhia das Letras, 1993.

RAMALHO, J.R. O mundo do crime: a ordem pelo avesso. Rio de Janeiro, Graal, 1979.

VIRILIO, P. La maquina de vision. Madrid, Catedra, 1989. 1990, p.82-92.

"A luz indireta". 34 Letras. Rio de Janeiro, Ed. 34, n.7, março

"A imagem virtual mental e instrumental". In: PARENTE, A. (org.). Imagem-máquina: a era das tecnologias do virtual. Rio de Janeiro, Ed. 34, 1993a.

. O espaço crítico e as perspectivas do tempo real. Rio de Janeiro, Ed. 34, 1993b. 